\title{
Ultrastructure of bovine placenta during all gestational period
}

\author{
[Ultraestrutura de placenta bovina durante todo o período gestacional] \\ R.B. Santos ${ }^{1}$, J.M. Silva ${ }^{2}$, M.E. Beletti ${ }^{2}$ \\ ${ }^{1}$ Universidade Federal de Uberlândia e Universidade Federal de Goiás - Uberlândia, MG \\ ${ }^{2}$ Universidade Federal de Uberlândia - Uberlândia, MG
}

\begin{abstract}
Placentas from pregnant cows with different gestation periods were used. Placental fragments of all groups were processed and evaluated by transmission electron microscopy. After fragment analysis, bovine placenta was observed to be epitheliochorial type in early pregnancy, becoming progressively sinepiteliocorial at the beginning of the second trimester. There are no ultrastructural evidences of inflammation in the region of caruncles throughout gestation, despite the invasion of caruncle proper lamina by trophoblast cells. However, throughout pregnancy and especially at the end, there were evident signs of cell degeneration in both trophoblast and the uterine epithelium. The active trophoblast cells intensely phagocytize cellular debris. There are complex interdigitations between the surface of the trophoblast and the uterine epithelium, which is related to the increase of the exchange surface between mother and fetus. At the end of pregnancy, interdigitations disappear, favoring the detachment and expulsion of the placenta after birth.
\end{abstract}

Keywords: bovine placenta, ultrastructure, maternal-fetal interaction, cotyledon, caruncles

\section{RESUMO}

Foram utilizadas placentas de vacas abatidas em frigorífico com diversos tempos gestacionais. Fragmentos de placentomo de todos os grupos foram processados e avaliados em microscopia eletrônica de transmissão. Após análise dos fragmentos, observou-se que a placenta bovina é do tipo epiteliocorial no início da gestação, tornando-se sinepiteliocorial progressivamente a partir do início do segundo mês de gestação. Não existem evidências ultraestruturais de inflamação na região das carúnculas durante toda a gestação, apesar da invasão da lâmina própria caruncular por células trofoblásticas. No entanto, durante toda a gestação e em especial ao seu final, foram observados sinais evidentes de degeneração celular, tanto do trofoblasto como do epitélio uterino. As células trofoblásticas ativas fagocitam intensamente os debris celulares originados dessas degenerações. Existem complexas interdigitações entre a superfície do trofoblasto e do epitélio uterino, o que estaria relacionado com o aumento da superfície de troca entre mãe e feto. Ao final da gestação, praticamente desaparecem essas interdigitações, favorecendo o descolamento e a expulsão da placenta após o parto.

Palavras-chave: placenta bovina, ultraestrutura, interação materno-fetal, cotilédone, carúnculas

\section{INTRODUCTION}

The placenta is a structure composed of placentomes, trophoblastic cells, fetal membranes, allantoic, and amniotic fluids (Peter, 2013). Its implantation is a complex process that involves many biochemical factors and molecular modifications, such as contact between cells with different origins, cellular invasion and/or fusion, depending on the species, type of placentation, proliferation of endometrial cells and reorganization of the extracellular matrix (ECM) (Sugawara et al., 2010).

In the endometrium of ruminants these events occur in a limited area called caruncle (Klisch et al., 1999; Hashizume et al., 2007; Sugawara et al., 2010). The placentome, which constitutes the

Recebido em 28 de abril de 2016

Aceito em 9 de julho de 2016

E-mail: raisabrito@hotmail.com 
union of the maternal caruncle and the fetal cotyledon, is the functional unity of the placenta (Cazerta et al., 2007). These placentomes are covered in a single layer of trophoblastic cells, which is formed, predominantly, by mononuclear cells and the presence of giant cells is also observed. Mononuclear cells have irregular shape, with round nuclei and big nucleolus, which are projected from distal portions of the crypts (Will et al., 2010).

In cow's placentome the spiral relation between veins and arteries is not observed. As in the umbilical one, veins are also of great diameter and length, and these facts foster researches based on transplants of these vessels to other organs. (Kakabadze e Kakabadze, 2015).

Bovine cotyledon is constituted of several tenuous and branched chorionic villis. This ramification increases as pregnancy advances, forming secondary and tertiary villus, intensively vascularized, which intermixes in the maternal caruncular criptas. Each villus is composed by a vascular mesenchyme, covered by trophoblastic cells (Cazerta et al., 2007).

Giant trophoblastic cells occupy different positions between mononuclear cells, and at times also encounter themselves in uterine epithelium, as a result of trophoblastic epithelial cells migration. Most of these giant cells are completely surrounded by their mononuclear cells and there is no connection to the basal membrane. It is observed that maternal endometrium epithelium remains intact because there is no trophoblastic invasion; there is only an epithelium insertion. (Will et al., 2010).

A frequent problem in dairy cattle is fetal membrane retention, causing losses due to reproductive efficiency reduction. Fetal membranes contain more abundant extracellular matrix than collagen fibers. Animals with placenta retention demonstrate differences in these elements in comparison to healthy animals. Another difference observed is in cellular junctions, in which cells of animals with retentions are more connected, which is due to a dysfunction of the apoptotic signal, in association with the reduction of the FAS apoptotic factor. (Kamemori et al., 2011).
Histochemistry proliferation and apoptosis show specific patterns on the pregnancy phase, as well as to individual types of cells during pregnancy. These events play an important role in placental growth and regeneration, and fetal nutrition. After the delivery, apoptosis possibly reflects in uterine reduction and fetal annex expulsion, it can be observed that 3 hours after fetal expulsion, the blood flow reduces around $70 \%$ in comparison to the values before delivery. (Boos et al., 2003).

A single layer of cubic cells forms the uterine epithelium. Right underneath the epithelium, the endometrial stroma distinguishes in considerable quantities of thick bundles of collagen fibers and blood vessels. During pregnancy, hematophagous areas are observed and those are characterized by the accumulation of maternal blood extravasated in the interstice between the uterine and trophoblastic epithelium, besides a big accumulation of lipid vesicles and hematogen pigments. On an advanced period of pregnancy, of 7-8 months, the presence of erythrocytes is observed in the interior of the trophoblast epithelial cells due to the erythrophagocytosis, suggesting a possible transfer of iron to the fetus (Cazerta et al., 2007).

In the fetal-maternal interface, its many layers can be visualized: fetal endothelium, mesenchyme (fetal tissue), chorionic epithelium or trophoblastic, uterine epithelium, endometrial stroma (breast tissue) and from maternal endothelium. The interplacentomal region present in both uterine horns form part of the chorioallantoic membrane, which does not have placentomes. In this region, the chorion is adhered to the endometrium, except in the regions where the uterine glands open (Will et al., 2010). Thus, the study of placental morphologies characteristics in its evolution during pregnancy will help to characterize its phases, making it easier to understand what happens in each period. Studies about how pregnancy events help or disturb bovine productive quality can be a leap in the field of reproduction. The present work ultra-structurally analyzes placental stages, using transmission electronic microscopy, observing the morphological composition of its components, which influence the continuation of pregnancy. 


\section{MATERIALS AND METHODS}

This research was evaluated and approved by the Animal Ethics Committee (protocol number 053/09 - Comitê de Ética na Utilização de Animais) of the Federal University of Uberlândia. Placentas collected after cow slaughter at a slaughterhouse (Frigorífico Luciana, Uberlândia, Minas Gerais, Brazil) with several gestational times were used. Placentas were distributed into five groups: Group 1: up to a month of gestation. Group 2: 2 to 3 months of gestation, group 3: 4 to 5 months of gestation, group 4: 6 to 7 months of gestation, group 5: 8 to 9 months of gestation.

Each group was composed of five-gestant uterus, of which fragments of at least three placentomes with aleatory location were collected. The embryo's age was estimated based on the following formula: $\mathrm{DG}=8,4+0,087 \mathrm{C}+5,46$ $\sqrt{ } \mathrm{C}$, where: $\mathrm{DG}=$ gestation days and $\mathrm{C}=$ embryo or fetal length according to Rexroad et al., 1974. After the embryo was removed from the uterus, its length was measured in millimeters $(\mathrm{mm})$ from the cephalic vertex curvature to the coccigeo (craniocaudal length or crown-rump), and such procedure was always performed by the same person (Diniz et al., 2005).

All material collected was fixed by immersion in glutaraldehyde at $3 \%$ in phosphate tampon $\mathrm{pH}$ 7,4 from 1 to 3 hours. Posteriorly, three washes

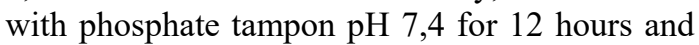
two for 5 minutes each, were conducted. After that, a post fixation in $1 \%$ osmium tetroxide for 30 minutes and more 30 minutes in $1 \%$ osmium tetroxide with Ferro cyanide potassium 1,25\% was performed. After this stage, fragments were dehydrated in solutions with crescent concentration of acetone and included in Epon 812 resin. Obtained resin blocks were cut in ultra-microtome, obtaining ultra slim cuts (60 to $90 \mathrm{~mm}$ ), which were contrasted in uranyl acetate and lead citrate. The evaluation of these cuts was performed in a Zeiss EM 109 transmission electronic microscope of ICBIM-UFU Histology Laboratory, and the documentation through digital images was done in a Megaview 5 equipment.

\section{RESULTS}

At group 1 (until the first month of gestation), it was possible to observe uterine crypts, which agrees with Wood and Burton (2008), coated by simple prismatic epithelium with cilia and villi. Between the epithelium and the conjunctive tissue of the endometrium proper lamina, there is a thin basal lamina (Figure 1.A). The proper uterine lamina is constituted by a conjunctive tissue rich in collagen fibers, fibroblasts, blood vessels and, eventually, isolated lymphocytes (Figure 1.B). The trophoblast (chorion's most external layer) is constituted by uni and binucleate cells (Figure 1.C). Part of these cells have a big nucleus with a spherical tendency shape, with clear chromatin and at least one evident nucleolus, clear cytoplasm with few organelles, among which, well-structured mitochondria, smooth and granular endoplasmic reticulum. Other trophoblastic cells, beyond similar organelles, also have a great number of granules of varied electron density, with a predominance of the ones with high electron density (Figure 1.D). These granules usually have polarized distribution, with a greater concentration on the cell side that is turned to the trophoblast's basal lamina, which is clearly thicker than the one found in the uterine epithelium.

Chorion mesenchymal is poor in cells and fibers, rich in amorphous fundamental substances and blood vessels. Corium-epithelium transitions are characterized by well-defined epithelium and trophoblast, but with an intricate interdigitated surface (Figure 2.A). At some points it is also possible to observe uterine epithelium in degeneration process and being phagocytized by trophoblastic cells (Figure 2.B).

Group 2 (between two and three months of pregnancy) structures very similar to the first month of pregnancy were observed. Among the evidenced modifications, it can be mentioned that the chorion basal lamina presented itself more undulated and with a great number of the mesenchymal blood vessels juxtaposed to it (Figure 3.A e 3.B). All uterine epithelium cells presented a greater degeneration level, evidenced by the cytoplasmic dilatation and nucleus and organelles disaggregation. Superficial trophoblastic cells presented the greatest number of microvillus and frequently touched the basal lamina of the uterine epithelium. Apparently, trophoblastic cells presented a greater number of mitochondria and the proper lamina of caruncle had the greatest cells number. 

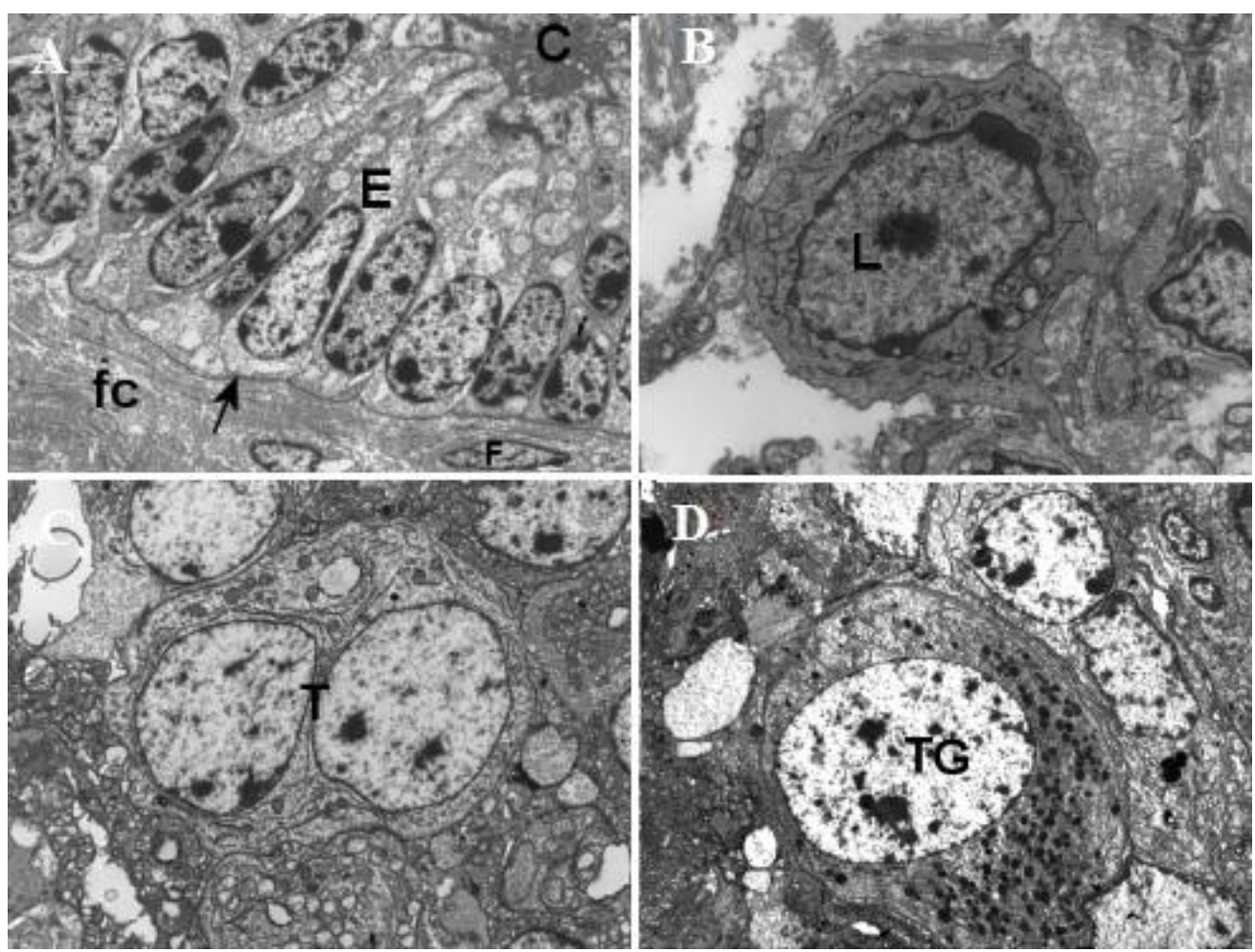

Figure 1. A) Electromyography of the internal surface of the bovine uterine caruncle of a group 1 placentome. Observe the simple prismatic epithelium (E), with cilia and microvilli (C), thin basal lamina (arrow), proper lamina with collagen fiber (fc), and fibroblasts (F). 3.000x increase. B) Electromyography of the proper lamina of the bovine uterine caruncle of a group 1 placentome. Observe the typical lymphocyte (L). 7.000x increase C) Electromyography of bovine uterine-trophoblast epithelium transition of a group 1 placentome. Observe the binucleate trophoblastic cell (T). 4.400x increase. D) Electromyography of the bovine uterine-trophoblast epithelium transition of a group 1 placentome. Observe the mononuclear trophoblastic cell (TG) with electron dense granules. $3.000 \mathrm{x}$ increase. Zeiss EM 109 transmission electron microscope.
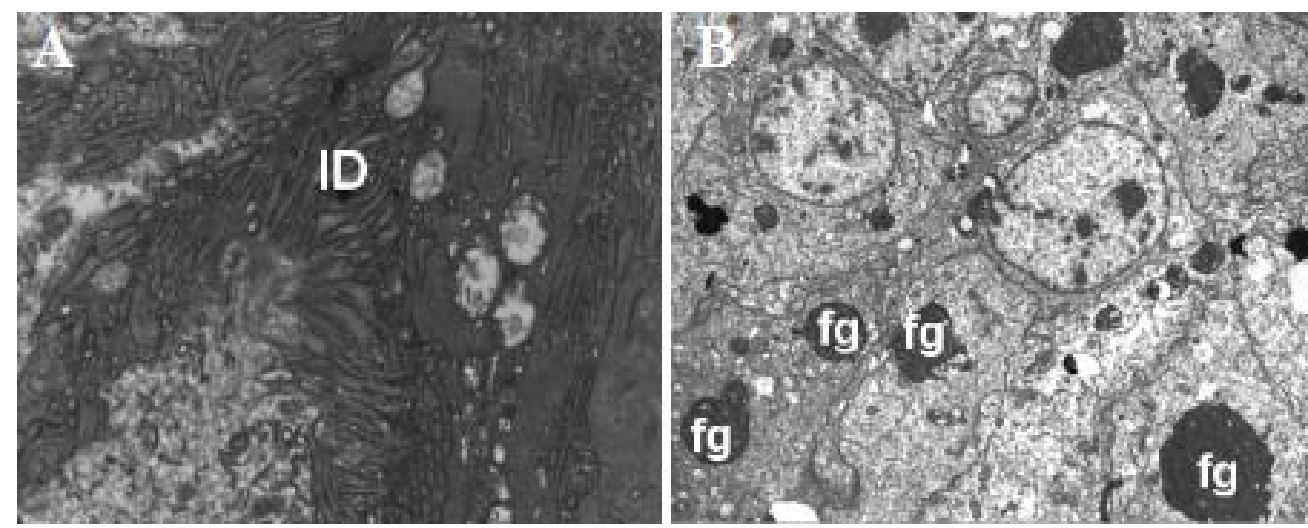

Figure 2. Electromyography of the epithelium uterine-trophoblastic transition of a group 1 bovine placentome. Observe the interdigitated (id) surfaces between the two cell layers. 12000x increase B) Electromyography of the epithelium uterine-trophoblastic transition of a group 1 bovine placentome. Observe trophoblastic cells with big phagosomes (fg) containing residues of uterine epithelial cells. 3000x increase. Zeiss EM 109 transmission electron microscopy. 


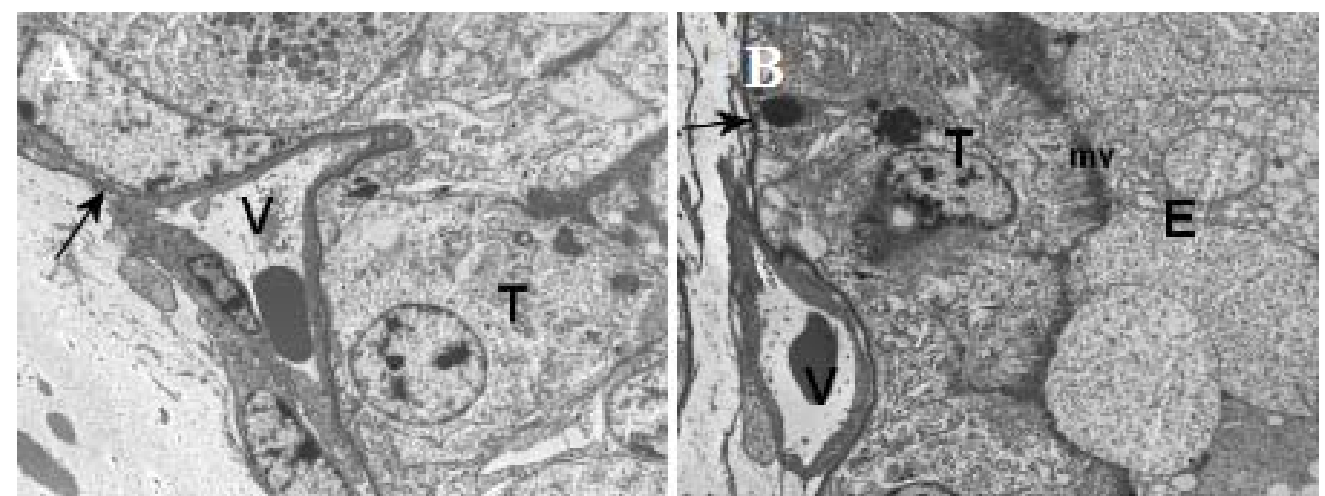

Figure 3. A) Electromyography of the trophoblast-mesenchymal transition of a group 2 bovine placentome. Observe the trophoblastic cells (T) supported over an irregular basal lamina (arrow) with blood vessels (V) juxtaposed mesenchymal. B) Electromyography of the trophoblast-mesenchymal transition of a group 2 bovine placentome. Observe trophoblastic cells (T) supported over an irregular basal lamina (arrow) with blood vessels (V) juxtaposed mesenchymal and microvilli (mv) of trophoblastic cells touching degenerate uterine epithelial cells (E). 3.000x increase. Zeiss EM 109 transmission electron microscope.

For pregnant animals, between four and five months of gestation, from group 03, significant similar structures from group 02 were observed, few uterine epithelial cells, observing, in many occasions, trophoblastic microvilli amidst cellular debris as shown in Figure 4.A. Eventually, epithelial uterine basal lamina ruptures were observed and also the presence of some trophoblastic cells in the most superficial regions of the specific endometrial lamina.
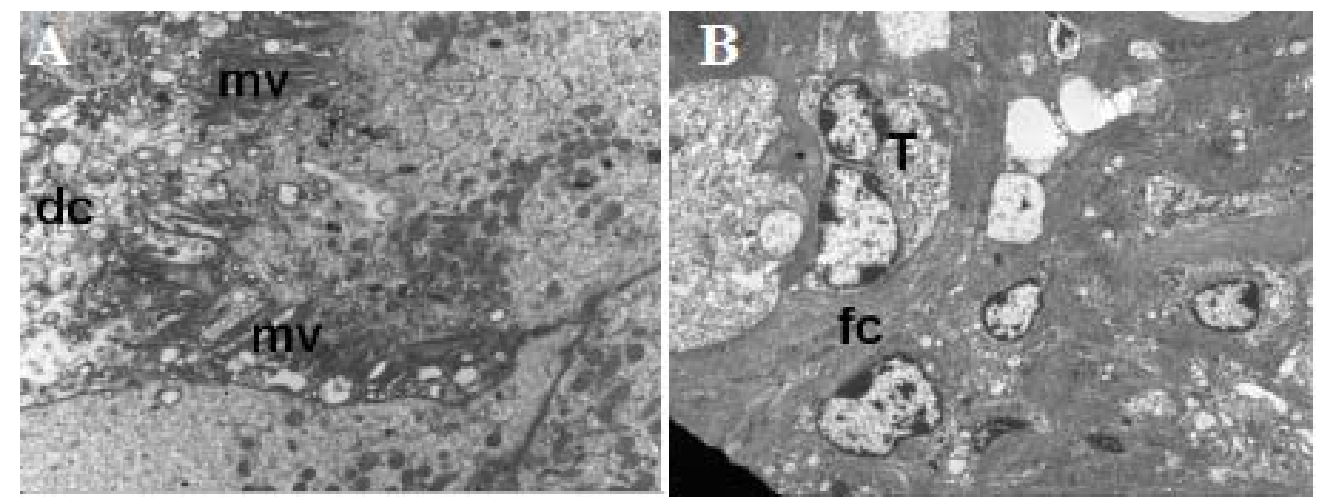

Figure 4. A) Electromyography of the epithelium uterine-trophoblastic transition of a group 3 bovine placentome. Observe trophoblastic cells with a great microvilli number $(\mathrm{mv})$ in cellular debris $(\mathrm{dc}) .7000 \mathrm{x}$ increase. B) Electromyography of a placental bovine uterine specific lamina of group 3. Observe trophoblastic cell (T) in relation to collagen fibers (fc) of the specific lamina. 3000x increase. Zeiss EM 109 transmission electron microscopy.

In relation to group 4 (between six and seven months of pregnancy), ruptures of uterine epithelium basal lamina and the presence of some trophoblastic cells in more superficial regions of the endometrial proper lamina (5.A) were frequently observed. In Figure 5.B, mesenchymal apparently presented greater collagen fibers quantity than in relation to previous pregnancy months, but still few fibers compared to uterine proper lamina. 

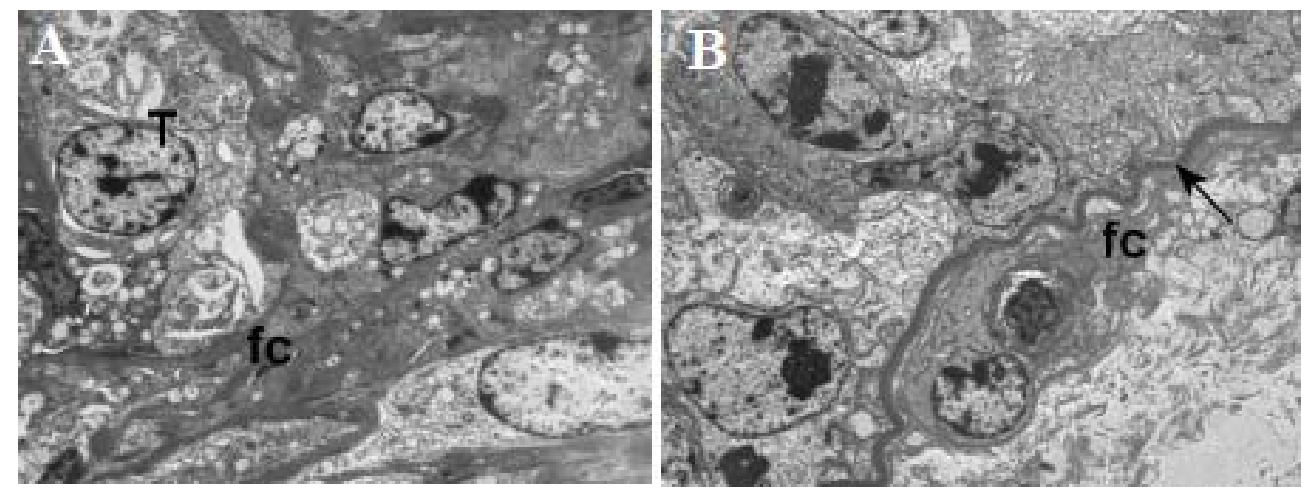

Figure 5. A) Electromyography of the uterine proper lamina of a group 4 bovine placentome. Observe trophoblastic cell $(\mathrm{T})$ in collagen fibers (fc) pf the proper lamina. B) Electromyography of the mesenchymal-trophoblast transition of a group 4 bovine placentome. Observe thick basal lamina (arrow) and mesenchymal with collagen fibers (fc). 3000x Increase. Zeiss EM 109 transmission electron microscopy.

However, at group 5 (between eight and nine months of pregnancy) a greater invasion of trophoblastic cells on the surface of the specific caruncle lamina was observed (Figure 6.A). The mesenchyme showed even more collagen fibers, less caliber vessels and more structured walls (Figure 6.B)
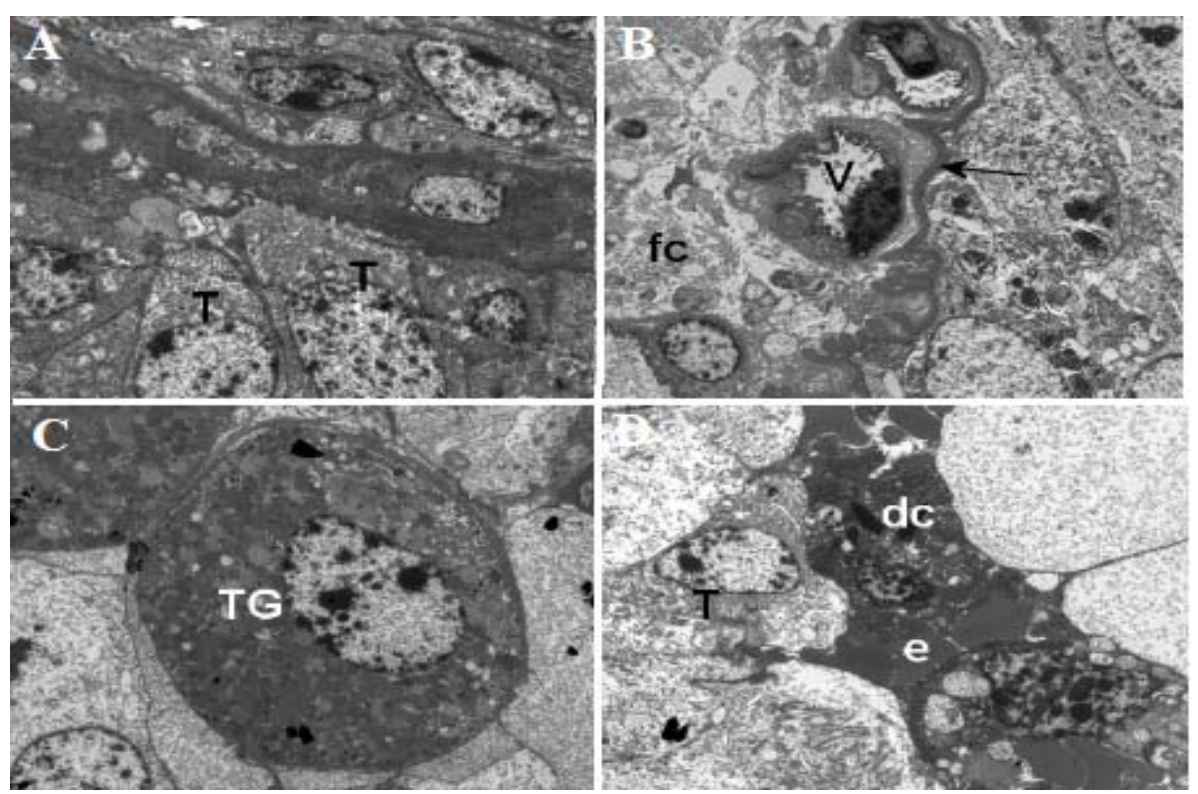

Figure 6.A) Electromyography of a uterine lamina of a group 5 bovine placentome. Observe the trophoblastic cell $(\mathrm{T})$ invading the proper lamina. B) Electromyography of the trophoblast-mesenchymal transition of a group 5 bovine placentome. Observe the thick basal lamina (arrow) and mesenchyme with collagen fibers (fc) and structured blood vessels (V). C) Electromyography of bovine trophoblastic cells (TG) full of granules of a group 05 placentome. D) Trophoblast electrophromicrography of a group 5 bovine placentome. Observe whole erythrocytes (e) and cellular debris (dc) between trophoblastic cells (T) with clear signs of degeneration. 3.000x increase. Zeiss EM 109 transmission electron microscope. Trophoblastic cells with granules presented a greater quantity of granules (Figure 6.C). A great number of trophoblastic cells presented signs of degeneration, and there were few uterine epithelial cells. Erythrocytes between these cells were often observed (Figure 7.D) 


\section{DISCUSSION}

According to the current literature, in the beginning of pregnancy, cattle presents a epitheliochorial placenta, with all six layers that compose the hemato placental or inter hematic barrier. As pregnancy develops, placenta becomes sinepiteliocorial, due to the migration of binucleate trophoblastic cells to the uterine epithelium (Leiser and Kaufmann, 1994, Wooding 1992).

After extensive review on the trophoblastic cells role in placenta, Igwebuike (2006) reaffirms ruminant's placenta as being, histologically sinepiteliocorial. Results of the present work structurally demonstrate that cow's pregnancy begins with an epitheliochorial placenta, and around the beginning of the second month, the first signals of placental transformation in sinepitelicorial appear. It can be affirmed that even though the trophoblast reaches the proper lamina of the uterine caruncle, this occurs in a very superficial way. However, there is no implantation process and the embryo/fetal changes are harder in this type of placenta, compared to hemochorial placentas. (Humans, primates, rodents, and lagomorphs), and endotheliochorial (carnivorous). On the other hand, sinepiteliocorial placentas are more efficient as barriers against infectious diseases vertical transmission and transplacental intoxications.

Besides the superficial invasion of caruncle proper lamina by the trophoblastic cells, no clear uterine inflammation signals were evidenced. This is in accordance with Gallo's (2012) observations, who evaluating the genic expression of some cytokines, also did not find inflammation signs up to the seventh month of pregnancy. However, suggestive alterations of inflammation at the end of the pregnancy were found. In the present work were observed clear signs of epithelial and trophoblastic degeneration, which could justify Gallo (2012) findings at the end of pregnancy, despite not discovering inflammatory infiltrates. This inflammation at the end of pregnancy would be necessary for a perfect expulsion of placenta and would avoid its retention (Davies et al., 2000; Benedictus et al., 2012).
The signs of degeneration are compatible to the ones found by Benetone (2005) on female buffalo, which found a high rate of apoptosis of these cells, especially in the final third of the gestation. Kamemori et al. 2011 confirmed the presence of apoptosis in the placenta using the marking of apoptotic factors such as FAS, CASP8, BAX, BCL2 and CASP3, and also compared these animals with and without placenta retention, visualizing that animals with retention presented FAS and CASP3 factor deficiency, and also maintain a greater expression of cFLIP RNA, which inhibits the apoptosis through CASP8 inactivation. In the present work it was evident that cellular debris from both the uterine epithelium and the trophoblastic cells are phagocytosed and digested by active trophoblastic cells.

The presence of interdigitations between the trophoblast surface and the uterine epithelium has already been described for other species $(\mathrm{Hu}$ e Cross, 2011) and is related to the increase of the exchange surface between mother and fetus. By the end of the gestation these interdigitations had practically disappeared, which favor the displacement and expulsion of the placenta after the birth.

Although the placental type of rats differs from ruminants, this serve as an experimental model for many animals. It is a known fact that for these animals there are several types of trophoblastic cells capable of differentiating into many cells with different functions. Simmons et al., 2007 cited a few types of trophoblastic cells associated to the formation of the spiral artery, to the maternal bloodstream and to placental sinusoids, and also the trophoblastic cells with glycogen granules. $\mathrm{Hu}$ and Cross, 2011, confirmed the function of trophoblastic cells in the formation of the spiral artery and consequent fetal nutrition through the ablation of $\mathrm{SpA}$ trophoblastic cells, animals presented a diminished lumen for this artery. Other types of trophoblastic cells with granulation are considered as food reserve cells, which would migrate to close or inside the uterus and from there would eliminate its content and would turn into apoptosis or other type of degeneration (Pinto et al., 2008). In the present work these cells were found above the first layer of trophoblastic cells going to close to the basal lamina of uterine epithelium, presenting granules 
preferable turned to the fetal portion (mesenchyme), contrary to what was described by Pinto et al. (2008). The greater quantity of granules on these cells at the end of the gestation can be through a slower turnover, which would give more time to the storage of granules.

In the ultra-micrographs presented was observed that during pregnancy development chorion mesenchymal presented an increase in collagen fibers and blood vessels quantity. Benetone (2005) also made similar observations in buffalo placentas. While Kamemori et al. (2011) evaluated the quantity of collagen fibers in cows with and without placental retention and on the first ones the chorion collagen fibers marking was lesser than in healthy animals. The increase of the quantity of collagen fibers in chorion makes the placenta of a less friable consistency, which is necessary to its non-shattering during delivery. The presence of a greater fibers quantity could difficult changes between mother and fetus, but this is compensated by the increase and greater structuration of mesenchymal vases.

\section{CONCLUSION}

In the beginning of gestation, bovine placenta is epitheliochorial type in early pregnancy, becoming progressively sinepiteliocorial from the start of the second trimester. There are not ultrastructural evidences of inflammation in the region of caruncles throughout gestation, despite the caruncle lamina proper invasion by trophoblastic cells. However, throughout pregnancy, and especially at the end, there were evident signs of cell degeneration in both the trophoblast and uterine epithelium. The active trophoblastic cells intensely phagocytize cellular debris. There are complex interdigitations between the surface of the trophoblast and of the uterine epithelium, which is related to the increase of the exchange surface between mother and fetus. At the end of pregnancy the interdigitations disappear, favoring the detachment and expulsion of the placenta after birth.

\section{ACKNOWLEDGEMENTS}

We thank CNPQ and Fapemig for the financial support, ICBIM- UFU for all the structure promptly available, and professor Marcelo Emílio Beletti for all his solicitude and patience.

\section{REFERENCE}

BENEDICTUS, L.; THOMAS, A.J.; JORRITSMA, R. et al. Two-way calf to dam major histocompatibility class I compatibility increases risk for retained placenta in cattle. Am. J. Reprod. Immunol., v.67, p.224-230, 2012.

BENETONE, M.Z. Apoptose e proliferação na placenta de búfalas. 2005. 186f. Dissertação (Mestrado em Ciências) - Faculdade de Medicina Veterinária e Zootecnia, Universidade de São Paulo, SP.

BOOS A.; JANSSEN V.; MULLING C. Proliferation and apoptosis in bovine placentomes during pregnancy and around induced and spontaneous parturition as well as in cows retaining the fetal membranes. Reproduction, v.126, p.469-480, 2003.

CAZERTA, S.M.M.; MIGLINO M.A.; MARQUES R.S. et al. Caracterização das áreas hemófagas da placenta bovina. Pesqui. Vet. Bras., v.27, p.229-235, 2007.

DAVID, G.; SIMMONS, A.; AMANDA, L. et al. Diverse subtypes and developmental origins of trophoblast giant cells in the mouse placenta. Dev. Biol., v.304, p.567-578, 2007.

DAVIES, C.J.; FISHER, P.J.; SCHLAFER, D.H. Temporal and regional regulation of major histocompatibility complex class I expression at the bovine uterine/placental interface. Placenta, v.21, p.194-202, 2000.

DINIZ, E.G.; ESPER, C.R.; JACOMINI, J.O.; VIEIRA, R.C. Desenvolvimento morfológico dos ovários em embriões e fetos bovinos da raça Nelore. Arq. Bras. Med. Vet., v.57, p.70-76, 2005.

GALLO, J.M.S. Antigeno Leucocitário Bovino (BoLA) de classe I e perfil de TGF-beta1 e TNFalfa em placenta durante a gestação. 2012. 91f. Tese (Doutorado em Imunologia e Parasitologia Aplicadas), Instituto de Ciências Biomédicas, Universidade Federal de Uberlândia, Uberlândia, MG.

HASHIZUME, K.; USHIZAWA, K.; PATEL, O.V. et al. Gene expression and maintenance of pregnancy in bovine: roles of trophoblastic binucleate cell-specific molecules. Reprod. Fertil. Dev., v.19, p.79-90, 2007. 
HU, D.; CROSS, J.C. Ablation of Tpbpa-positive trophoblast precursors leads to defects in maternal spiral artery remodeling in the mouse placenta. Dev. Biol., v.358, p.231-239, 2011.

IGWEBUIKE, U.M. Trophoblast cells of ruminant placentas: a minireview. Anim. Reprod. Sci., v.93, p.185-198, 2006.

KAKABADZE, A.; KAKABADZE, Z.; Prospect of using decellularized human placenta and cow placentome for creation of new organs: targeting the liver (part i: anatomic study. Transplant. Proc., v.47, p.1222-1227, 2015.

KAMEMORI, Y.; WAKAMIYA K.; NISHIMURA R. et al. Expressions of apoptosisregulating factors in bovine retained placenta. Placenta, v.32, p.20-26, 2011.

KLISCH, K.; PFARRER, C.; SCHULER, G. et al. Tripolar acytokinetic mitosis and formation of feto-maternal syncytia in the bovine placentome: different modes of the generation of multinuclear cells. Anat. Embryol., v.200, p.229-237, 1999.

LEISER, R.; KAUFMANN, P. Placental structure: in a comparative aspect. Exp. Clin. Endocrinol., v.102, p.122-134, 1994.

PETER, A.T. Bovine placenta: A review on morphology, components, and defects from terminology and clinical perspectives. Theriogenology., v.80, p.693-705, 2013.

PINTO, M.L.; AMBROSIO, E.C.; TEIXEIRA, G.D. et al. Comportamento das células trofoblásticas gigantes na placenta de vacas Nelore (Bosindicus -Linnaeus, 1758); Rev. Bras. Reprod. Anim., v.32, p.110-121, 2008.
SIMMONS D.G.; FORTIER A.L.; CROSS J.C.; Diverse subtypes and developmental origins of trophoblast giant cells in the mouse placenta. Dev. Biol., v.304, p.567-578, 2007.

SUGAWARA, K.; KIZAKI, K.; HERATH, C.B. et al. Transforming growth factor beta family expression at the bovine feto-maternal interface. Reprod. Biol. Endocrinol., v.8, p.120, 2010.

WILL, S.E.A.L.; RICI, R.E.G.; MIGLINO, M.A.; ANTUNES, A. Trace element of bovine placenta: histological analysis and distribution maps using $\mu$ SXRF. In: MÉNDEZ-VILAS, A.; DÍAZ, J. (Orgs.). Microscopy: science, technology, pplications and education. Badajoz: Formatex Research Center, 2010. p.1039-1046.

WOODING, F.B.P. Current Topic: The Synepitheliochorial Placenta of Ruminants: Binucleate Cell Fusions and Hormone Production. Placenta, v.13, p.101-1 13, 1992.

WOODING, F.B.P.; MORGAN, G.; MONAGHAN, S. et al. Functional specialization in the ruminant placenta" evidence for two populations of fetal binucleate cells of different selective synthetic capacity. Placenta, v.17, p.7586, 1996.

WOODING, P.; BURTON, G. Comparative placentation structures, functions and evolution. [s.1.]: Springer, 2008. 304p. 